\title{
Sources of Resistance to Stem Rust Race Ug99 in Spring Wheat Germplasm
}

M. N. Rouse, United States Department of Agriculture-Agricultural Research Service Cereal Disease Laboratory, University of Minnesota, St. Paul 55108; R. Wanyera and P. Njau, Kenya Agricultural Research Institute, National Plant Breeding Research Center, P.O. Njoro, Kenya; and Y. Jin, USDA-ARS Cereal Disease Laboratory, University of Minnesota, St. Paul 55108

\begin{abstract}
Rouse, M. N., Wanyera, R., Njau, P., and Jin, Y. 2011. Sources of resistance to stem rust race Ug99 in spring wheat germplasm. Plant Dis. 95:762766.

Wheat stem rust (Puccinia graminis f. sp. tritici) race TTKSK (Ug99), with virulence to the majority of the world's wheat (Triticum aestivum) cultivars, has spread from Uganda throughout eastern Africa, Yemen, and Iran. The identification and spread of variants of race TTKSK with virulence to additional stem rust resistance genes has reminded breeders and pathologists of the danger of deploying major resistance genes alone. In order to protect wheat from this rapidly spreading and adapting pathogen, multiple resistance genes are needed, preferably from improved germplasm. Preliminary screening of over 700 spring wheat breeding lines and cultivars developed at least 20 years ago identified 88 accessions with field resistance to Ug99. We included

these resistant accessions in the stem rust screening nursery in Njoro, Kenya for two additional seasons. The accessions were also screened with a bulk of North American isolates of $P$. graminis f. sp. tritici in the field in St. Paul, MN. In order to further characterize the resistance in these accessions, we obtained seedling phenotypes for 10 races of $P$. graminis f. sp. tritici, including two races from the race TTKSK complex. This phenotyping led to the identification of accessions with either adult-plant or all-stage resistance to race TTKSK, and often North American races of $P$. graminis f. sp. tritici as well. These Ug99 resistant accessions can be obtained by breeders and introgressed into current breeding germplasm.
\end{abstract}

Wheat stem rust, caused by Puccinia graminis f. sp. tritici Erikss. \& Henning, has historically been a major yield-limiting factor of wheat (Triticum aestivum L.). In the United States, epidemics of stem rust caused yield losses exceeding 50\% statewide in North Dakota and Minnesota in 1935 and exceeding $40 \%$ in North Dakota in 1954 (15). Intensive efforts in breeding for stem rust resistance and the removal of the alternate host of $P$. graminis f. sp. tritici in some locations led to the successful control of this disease both in the United States since 1955 and effectively worldwide over the last several decades (8). The occurrence and spread of the virulent $P$. graminis f. sp. tritici race TTKSK (Ug99) and its variants since initial detection in 1998 suggest that the world's wheat is once again threatened by stem rust $(1,3-6,10,13,14,18)$.

Several resistance genes effective against race TTKSK have been identified (4). However, many of these genes are of partial effect, are race specific, and are linked to undesirable traits on alien chromatin. Resistance available in adapted germplasm is conferred by relatively few resistance genes, including $S r 2, S r 25, S r 26$, SrCad, SrTmp, and SrIA.1R $(2,3,11,18)$. Additionally, a few cultivars and breeding lines exist with unknown resistance genes, including sources possessing adult plant resistance (11). Given the few available sources of resistance to race TTKSK and variants, their low frequency in adapted germplasm, and the rapid adaptation of these races to previously effective resistance genes, it is essential to identify and characterize additional sources of resistance. We screened over 700 spring wheat breeding lines and cultivars developed at least 20 years ago for resistance in the field in Kenya and St. Paul, MN. Eighty-eight accessions were identified as conferring various levels of resistance to Ug99 in the field. Our

Corresponding author: Y. Jin, E-mail: Yue.Jin@ ars.usda.gov

* The $e$-Xtra logo stands for "electronic extra" and indicates that two supplementary tables are available online.

Accepted for publication 21 February 2011.

doi:10.1094/PDIS-12-10-0940

This article is in the public domain and not copyrightable. It may be freely reprinted with customary crediting of the source. The American Phytopathological Society, 2011 objective was to characterize the stem rust resistance of these accessions by screening with multiple isolates of $P$. graminis $\mathrm{f}$. sp. tritici at both seedling and adult plant stages.

\section{Materials and Methods}

Greenhouse seedling screening. Seedling screening was performed with eight North American isolates of $P$. graminis $\mathrm{f}$. $\mathrm{sp}$. tritici and two isolates of $P$. graminis $\mathrm{f}$. $\mathrm{sp}$. tritici from Kenya (Table 1). Isolate 04KEN156/04 is race TTKSK (Ug99) and isolate 06KEN19-V-3 is race TTKST, which is the race TTKSK variant with additional virulence to gene $\operatorname{Sr} 24$ (4,5). All isolates were derived from single pustules, increased in isolation, and stored at $-80^{\circ} \mathrm{C}$. The 88 lines used in this study were obtained from the United States Department of Agriculture National Small Grains Collection (Aberdeen, ID). The accessions are listed in Table 2. Common names and pedigree information can be found in Supplementary Table 1 and online at http://www.ars-grin.gov/npgs/ index.html. A susceptible line, LMPG-6 (7), was used as a control in all evaluations. Two of the 88 lines, CI 14267 and CI 15853, have been reclassified as T. turgidum L. subsp. durum (Desf.) Husn. by National Small Grains Collection staff since the lines were obtained. Seedling screening with Kenyan isolates of $P$. graminis $\mathrm{f}$. sp. tritici was conducted only during the winter months of December, January, and February as a precaution to prevent the escape of these cultures.

For seedling screening assays, $P$. graminis f. sp. tritici urediniospores were retrieved from $-80^{\circ} \mathrm{C}$ storage, heat shocked at $45^{\circ} \mathrm{C}$ for $15 \mathrm{~min}$, placed in a rehydration chamber for 2 to $4 \mathrm{~h}$ maintained at $80 \%$ relative humidity by a $\mathrm{KOH}$ solution (17), and mixed with a light-weight mineral oil (Soltrol 70; ConocoPhillips Inc., Houston) in preparation for inoculation. Spores were inoculated onto the primary leaves of seedling plants 7 to 9 days following planting. The plants were placed under a fume hood to allow the oil to evaporate for approximately $30 \mathrm{~min}$. Inoculated plants were placed into a dew chamber for $14 \mathrm{~h}$ at $18^{\circ} \mathrm{C}$ in darkness, followed by an additional 3 to $4 \mathrm{~h}$ with fluorescent light. The plants were then placed in a greenhouse maintained at $18 \pm 2{ }^{\circ} \mathrm{C}$ with a photoperiod of $16 \mathrm{~h}$. Infection types were recorded on a 0-to- 4 scale 14 days post inoculation after Stakman et al. (19). The letter X was used to denote mesothetic reactions (all infection types occurring on the same leaf), $\mathrm{C}$ was used to denote extensive chlorosis associated 
with infection, and $\mathrm{N}$ was used to denote extensive necrosis. When an accession displayed a relatively low infection frequency (i.e., low density of uredinia on a given leaf area), the infection type was recorded followed by LIF (low infection frequency). Symbols + and - were sometimes used to describe relative size of pustules for each infection type classification. Five to six plants of each accession were evaluated for each inoculation with a unique $P$. graminis f. sp. tritici isolate. When accessions were heterogeneous for infection types, the infection type was recorded as the most frequent infection type, followed by $/$, followed by the next most frequent infection type. For the North American P. graminis f. sp. tritici isolates, the experiments were repeated. For 04KEN156/04, four replicates were conducted over a period of 2 years. A set of the standard North American stem rust differentials was included in each inoculation with each isolate.

Field adult-plant screening. In order to evaluate the 88 accessions at the adult plant stage for field resistance to both Kenyan and domestic $P$. graminis f. sp. tritici isolates, field trials were conducted both at St. Paul, MN and Njoro, Kenya. The lines were grown in Njoro from June through October in three seasons (2005 to 2007). In St. Paul, the lines were grown from April to August 2006.

In St. Paul, the 88 accessions were included as part of the stem and leaf rust ( $P$. triticina Erikss.) nursery used for screening U.S. spring wheat germplasm with domestic stem and leaf rust isolates. The field plots consisted of 2-m-long single-row plots. Plots were separated by $20 \mathrm{~cm}$ with $2-\mathrm{m}$ alleys. Alleys were alternatively planted with winter wheat or a mixture of cultivars selected for their susceptibility to stem or leaf rust ('Thatcher', 'Morocco', 'LMPG-6', and 'Rusty') to serve as spreaders. Spreader rows were planted 1 to 2 weeks before the experimental plots. Spreader and winter wheat rows were planted perpendicular to the experimental plots. In Njoro, the accessions were included as part of an international nursery established by the Kenyan Agricultural Research Institute (4). The plots consisted of single 2-m rows in 2005 and two 1-m rows in 2006 and 2007. Spreader rows of Ug99-susceptible 'Chozi' and 'Duma' were planted perpendicular to the experimental plots.

Epidemics of stem rust were initiated at St. Paul by the inoculation of spreader rows. A water suspension of bulked urediniospores of North American P. graminis f. sp. tritici races QFCSC, TPMKC, RKQQC, RCRSC, QTHJC, and MCCFC (Table 1) was inoculated onto spreader rows by injection into the elongating stems using a hypodermic needle. A stem in the spreader row was injected approximately every $2 \mathrm{~m}$ on each side of the spreader row at the jointing stage. A light mineral oil suspension of the bulked $P$. graminis f. sp. tritici races was sprayed onto the spreader rows using an Ulva+ sprayer (Micron Sprayers Ltd., Bromyard, UK) after heading stage. In Njoro, urediniospores were collected from experimental plots of Duma (which possesses Sr31). Urediniospores were mixed with talc powder and dusted onto the spreader rows. Surveys of $P$. graminis f. sp. tritici races present in the Njoro nursery indicated that race TTKSK was the only described race in 2005; race TTKSK predominated in 2006, with race TTKST present at a trace level; and both races TTKSK and TTKST predominated in 2007, with trace levels of race TTTSK being detected (6).
Infection response was classified for each line according to size of pustules and amount of chlorosis and necrosis (16). Infection response categories included resistant $(\mathrm{R})$, moderately resistant (MR), moderately susceptible (MS), and susceptible (S). If a line displayed multiple infection responses to stem rust, they were all recorded (example: MR-MS). Severity of stem rust was visually scored on the 0-to-100 modified Cobb scale (12). When lines were observed to be heterogeneous for infection response or severity, symbol " $/$ " was used to separate readings from different plants of the same line.

\section{Results}

The 88 accessions displayed a wide range of seedling infection types to race TTKSK (Table 2). Several accessions displayed infection types 3 to 4 , indicating that those lines possess only adult plant resistance to race TTKSK. Several accessions were observed to be heterogeneous in seedling infection types, indicating that the accessions contain mixed genotypes. Many of the accessions remained resistant across multiple years of field screening in Kenya (Table 2). Infection responses remained relatively stable over the different seasons while disease severity in 2005 was the highest These resistant selections are in sharp contrast to the high severity and susceptible infection responses observed on LMPG-6 in each of the three seasons. The infection responses and severities were lower in 2007 than in previous years for many of the lines. This is likely due to the relatively late planting date for these accessions during 2007.

Screening of the 88 accessions with eight North American $P$. graminis f. sp. tritici isolates at the seedling stage resulted in a broad range of infection types (Table 2; Supplementary Table 2). The diversity of the germplasm screened combined with the complex infection type patterns observed prevented gene postulation in these lines. All of the accessions were resistant in the field, except PI 254138 (susceptible in St. Paul, heterogeneous for reaction in Kenya in 2005, and resistant in Kenya in 2006 and 2007). A few accessions were resistant in the field but susceptible to many of the $P$. graminis f. sp. tritici isolates at the seedling stage. An extreme example of this was CI 12499, which was susceptible to all $P$. graminis f. sp. tritici isolates except BCCBC (not present in field nursery) at the seedling stage but resistant at the adult plant stage. This seedling infection type pattern is consistent with the presence of $\operatorname{Sr} 28$, though $S r 28$ is not expected to provide resistance in the field in St. Paul.

PI 234234 displayed very good resistance in 2005 but was rated as susceptible in 2007. We are unsure of the reason for this inconsistency. Similarly, accessions PI 234235 and PI 234236 were resistant in 2005 and 2006 but susceptible in 2007. Both of these accessions are derived from T. timopheevii Zhuk., Sr36 is derived from T. timopheevii, and race TTTSK (virulent to Sr36) was detected in 2007 alone; therefore, it is possible that these accessions possess Sr36. Resistance to races TTKSK and TTKST and susceptibility to races TPMKC and TTTTF exhibited by these accessions also is consistent with the presence of Sr36. Accession CI 15685 was also derived from T. timopheevii and infection types to the Kenyan isolates suggest that it may possess Sr36. Accession CI

Table 1. Races of Puccinia graminis f. sp. tritici used to screen U.S. spring wheat accessions

\begin{tabular}{lll}
\hline Race & Isolate & \multicolumn{1}{c}{ Virulence/avirulence formula } \\
\hline BCCBC & 74JBR-1-111 & 9g,17,McN/5,6,7b,8a,9a,9d,9e,9b,10,11,21,24,30,31,36,38,Tmp \\
MCCFC & 59KS19 & $5,7 \mathrm{~b}, 9 \mathrm{~g}, 10,17, \mathrm{McN}, \mathrm{Tmp} / 6,8 \mathrm{a}, 9 \mathrm{a}, 9 \mathrm{~d}, 9 \mathrm{e}, 9 \mathrm{~b}, 11,21,24,31,30,36,38$ \\
QFCSC & 06ND76C & $5,8 \mathrm{a}, 9 \mathrm{a}, 9 \mathrm{~d}, 9 \mathrm{~g}, 10,17,21, \mathrm{McN} / 6,7 \mathrm{~b}, 9 \mathrm{e}, 9 \mathrm{~b}, 11,24,31,30,36,38, \mathrm{Tmp}$ \\
QTHJC & 75ND717C & $5,6,8 \mathrm{a}, 9 \mathrm{~b}, 9 \mathrm{~d}, 9 \mathrm{~g}, 10,11,17,21, \mathrm{McN} / 7 \mathrm{~b}, 9 \mathrm{a}, 9 \mathrm{e}, 24,30,31,36,38, T \mathrm{Tmp}$ \\
RCRSC & 77ND82A & $5,7 \mathrm{~b}, 9 \mathrm{a}, 9 \mathrm{~b}, 9 \mathrm{~d}, 9 \mathrm{~g}, 10,17,21,36, \mathrm{McN} / 6,8 \mathrm{a}, 9 \mathrm{e}, 11,24,30,31,38, \mathrm{Tmp}$ \\
RKQQC & 99KS76A & $5,6,7 \mathrm{~b}, 8 \mathrm{a}, 9 \mathrm{a}, 9 \mathrm{~b}, 9 \mathrm{~d}, 9 \mathrm{~g}, 21,36, \mathrm{McN} / 9 \mathrm{e}, 10,11,17,24,30,31,38, \mathrm{Tmp}$ \\
TPMKC & 74MN1409 & $5,7 \mathrm{~b}, 8 \mathrm{a}, 9 \mathrm{~d}, 9 \mathrm{e}, 9 \mathrm{~g}, 10,11,17,21,36, \mathrm{Tmp}, \mathrm{McN} / 6,9 \mathrm{a}, 9 \mathrm{~b}, 24,30,31,38$ \\
TTTTF & 01MN84A-1-2 & $5,6,7 \mathrm{~b}, 8 \mathrm{a}, 9 \mathrm{a}, 9 \mathrm{~b}, 9 \mathrm{~d}, 9 \mathrm{e}, 9 \mathrm{~g}, 10,11,17,21,30,36,38, \mathrm{McN}, \mathrm{Tmp} / 24,31$ \\
TTKSK & 04KEN156/04 & $5,6,7 \mathrm{~b}, 8 \mathrm{a}, 9 \mathrm{a}, 9 \mathrm{~b}, 9 \mathrm{~d}, 9 \mathrm{e}, 9 \mathrm{~g}, 10,11,17,30,31,38, \mathrm{McN} / 24,36, \mathrm{Tmp}$ \\
TTKST & 06KEN19-V-3 & $5,6,7 \mathrm{~b}, 8 \mathrm{a}, 9 \mathrm{a}, 9 \mathrm{~b}, 9 \mathrm{~d}, 9 \mathrm{e}, 9 \mathrm{~g}, 10,11,17,24,30,31,38, \mathrm{McN} / 36, \mathrm{Tmp}$ \\
\hline
\end{tabular}

a $\operatorname{Sr} 21$ is not included in the formula for races TTKSK or TTKST because the reaction of these races is not certain (4). 
14142 has WRT 238-5 in its pedigree ( $\mathrm{Sr} 27$ genetic stock), suggesting that this accession might possess gene $\mathrm{Sr} 27$. The resistant infection types to all races screened exhibited by CI 14142 is also consistent with the presence of $\mathrm{Sr} 27$.

\section{Discussion}

Screening of over 700 accessions of spring wheat resulted in the identification of 88 with field resistance to Ug99. Though the frequency of resistance to $\mathrm{Ug} 99$ in this germplasm is low, the number of resistant lines is promising for the identification of new resistance and introgression of resistance into currently grown cultivars. Nearly all of the lines that were identified as resistant in the field to Ug99 were also resistant in the field to North American isolates of P. graminis f. sp. tritici (Table 2). This suggests that either the resistance effective to $\mathrm{Ug} 99$ also confers resistance to North American isolates or that the accessions contain multiple resistance genes that confer resistance to a broad range of isolates. Regardless of the mechanism, the characterization of stem rust resistance in these accessions indicates that they are valuable for providing resistance to $\mathrm{Ug} 99$ as well as North American isolates of $P$. graminis f. sp. tritici.
It has been proposed that lines that are susceptible at the seedling stage but resistant at the adult plant stage possess resistance that will be durable (18). Several sources of resistance have been identified in International Maize and Wheat Improvement Center (CIMMYT) wheat breeding germplasm that are susceptible to race TTKSK at the seedling stage but exhibit a high level of resistance at the adult plant stage (11). These sources are being used extensively as parents of breeding populations for use worldwide (18). We identified 16 lines that are susceptible to races TTKSK and TTKST at the seedling stage (infection types 3 to 4) yet resistant in the field (Table 2). Ten of these lines are from hard red spring wheat breeding programs in the North American northern Great Plains, including six from the University of Minnesota. Many of the lines with adult plant resistance have Thatcher wheat in their pedigrees, and at least two (CI 11781 and CI 12040) are derived from line $\mathrm{H}-44$, which possesses the adult plant resistance gene Sr2. H-44, Thatcher, and Chris (a Thatcher derivative) are supposed to be the source of adult plant resistance observed in older CIMMYT wheat cultivars that were deployed widely as part of the Green Revolution (18). Further studies will be necessary to determine the genetics of stem rust resistance in these accessions. It is

Table 2. Seedling infection types and adult plant infection responses and severities of Triticum aestivum accessions to Ug99

\begin{tabular}{|c|c|c|c|c|c|c|c|c|}
\hline Accession & TPMKC & TTTTF & TTKSK $^{\mathbf{b}}$ & TTKST & 2005 Njoro & 2006 Njoro & 2007 Njoro & 2006 St. Paul \\
\hline CI 11649 & 3 & 3 & $3(23,4) \mathrm{H}$ & 4 & $40 \mathrm{MR}$ & $30 \mathrm{MS}$ & $1 \mathrm{MS}$ & $5 \mathrm{MR}-\mathrm{MS}$ \\
\hline CI 11781 & 4 & 4 & $4(3+, 4)$ & 4 & $20 \mathrm{MR}$ & $30 \mathrm{~S}$ & $1 \mathrm{M}$ & $5 \mathrm{MR}-\mathrm{MS}$ \\
\hline CI 11782 & $3-$ & 3 & ;13 (;,3)H & 3 & $10 \mathrm{MR}$ & $1 \mathrm{R}$ & $1 \mathrm{MR}$ & $5 \mathrm{R}$ \\
\hline CI 11783 & $22+$ & 4 & $; 1(0 ;, 4) \mathrm{H}$ & $3+$ & $10 \mathrm{MR}$ & $10 \mathrm{MS}$ & $1 \mathrm{MS}$ & $\mathrm{T} \mathrm{R}$ \\
\hline CI 11945 & 3 & $32+$ & $0 ;(0,3) \mathrm{H}$ & 0 & $10 \mathrm{R}$ & $1 \mathrm{R}$ & $1 \mathrm{MR}$ & $10 \mathrm{MR}-\mathrm{MS}, \mathrm{TS}$ \\
\hline CI 12040 & 3 & 3 & $3+(3,4)$ & 3 & $30 \mathrm{M}$ & $5 \mathrm{MR}$ & $1 \mathrm{R}$ & $5 \mathrm{R}$ \\
\hline CI 12044 & 3 & $42+$ & $\mathrm{X}-(; 2+, \mathrm{X}-)$ & $3-;$ & $20 \mathrm{MR}$ & $2 \mathrm{MR}$ & $1 \mathrm{R}$ & T MR \\
\hline CI 12048 & 4 & $3+$ & $0 ;(0 ;, ; 3)$ & $0 ; 1+$ & $20 \mathrm{MR}$ & $5 \mathrm{R}$ & $1 \mathrm{R}$ & $\mathrm{T} \mathrm{R}$ \\
\hline CI 12303 & $3+$ & 32 & $0 ;(0 ;, ; 3)$ & ;3 & $20 \mathrm{MR}$ & $2 \mathrm{R}$ & $1 \mathrm{R}$ & $5 \mathrm{MR}$ \\
\hline CI 12324 & $3+$ & 32 & ;3 $(0,3) \mathrm{H}$ & ;3- & $10 \mathrm{MR}$ & $1 \mathrm{R}$ & $1 \mathrm{R}$ & T R-MR \\
\hline CI 12355 & $3+$ & 4 & $; 13(0 ;, 3) \mathrm{H}$ & ;3 & $60 \mathrm{~S} / 20 \mathrm{MR}$ & $1 \mathrm{R}$ & $1 \mathrm{R}$ & $\mathrm{T} \mathrm{R}$ \\
\hline CI 12433 & $3+$ & 32 & $0(0, ; 3)$ & ;13 & $5 \mathrm{R}$ & 0 & $1 \mathrm{R}$ & T R \\
\hline CI 12499 & $3+$ & $3+$ & ;3 (;,3)H & ;3- & $10 \mathrm{M}$ & $1 \mathrm{MR}$ & $1 \mathrm{R}$ & $\mathrm{T} \mathrm{R}$ \\
\hline CI 12636 & 4 & $3+$ & ;3 (;,;3) & ;3 & $20 \mathrm{MR}$ & $5 \mathrm{MR}$ & $1 \mathrm{R}$ & $5 \mathrm{MR}$ \\
\hline CI 12699 & 2 & $2-$ & $4(1,4) \mathrm{I}$ & $2+3$ & $40 \mathrm{M}$ & $5 \mathrm{MR}$ & $10 \mathrm{MS}$ & $\mathrm{T} \mathrm{R}$ \\
\hline CI 12737 & 3 & 3 & ;3 $(0, ; 3)$ & ;23 & $20 \mathrm{MR}$ & $1 \mathrm{R}$ & $1 \mathrm{R}$ & $5 \mathrm{MR}$ \\
\hline CI 12780 & 3 & $3-$ & ;3 $(0,3) \mathrm{H}$ & 3 & $40 \mathrm{MR}$ & $1 \mathrm{R}$ & $1 \mathrm{MS}$ & $5 \mathrm{~S}$ \\
\hline CI 12899 & ;N & 2 & $\mathrm{X}-\mathrm{N}(; 1,3+) \mathrm{H}$ & $; 3 / 3$ & $10 \mathrm{MR}$ & $10 \mathrm{MS}$ & $1 \mathrm{R}-\mathrm{MR}$ & $\mathrm{T} \mathrm{MR}$ \\
\hline CI 13100 & $; 2 \mathrm{~N}$ & 3 & $4(3,4)$ & $3+$ & $20 \mathrm{MS}$ & $10 \mathrm{MR} / 10 \mathrm{~S}$ & $1 \mathrm{MR}$ & T R-MR \\
\hline CI 13204 & $1+$ & $1++$ & $X+(2, X+)$ & $; 13$ & $80 \mathrm{~S} / 10 \mathrm{MR}$ & $10 \mathrm{M}$ & $1 \mathrm{R}-\mathrm{MR}$ & 0 \\
\hline CI 13407 & 2 & $2+/ 3+$ & $0(0, ; 1-)$ & $; 1$ & $10 \mathrm{R}$ & $1 \mathrm{R}$ & $5 \mathrm{M}$ & 0 \\
\hline CI 13586 & $; 3 \mathrm{~N}$ & $; 1+$ & $X_{-}$ & $3-$ & $20 \mathrm{MS}$ & $5 \mathrm{MS}$ & $1 \mathrm{R}$ & TR \\
\hline CI 13652 & $2++$ & 0 & $;(0 ;, ; 12+)$ & ;13- & $10 \mathrm{MR}$ & $5 \mathrm{M}$ & $1 \mathrm{R}$ & 0 \\
\hline CI 13773 & 2 & 0 & $;(;, ; 11+)$ & ;13- & $20 \mathrm{MR}$ & $10 \mathrm{MS}$ & $1 \mathrm{R}$ & T R-MR \\
\hline CI 14142 & ; & $; 1$ & $;(;, \mathrm{X})$ & ; & $20 \mathrm{MR}$ & $1 \mathrm{R}$ & $1 \mathrm{R}$ & 0 \\
\hline CI 14249 & $; 1$ & $3-$ & $; 12+(0 ;, ; 12+)$ & 0 & $20 \mathrm{MR}$ & $5 \mathrm{M}$ & $10 \mathrm{M}$ & T R \\
\hline CI 14267 & $; 1$ & ; & $2-(2-, 2+3)$ & $2 \mathrm{~N}$ & $20 \mathrm{MR}$ & $5 \mathrm{R}$ & $10 \mathrm{R}-\mathrm{MR}$ & 0 \\
\hline CI 14275 & $; 13$ & $1+++\mathrm{LIF}$ & $; 12(; ; ; 12)$ & ;2 & $20 \mathrm{MR}$ & $5 \mathrm{MR}$ & $\ldots$ & 0 \\
\hline CI 14282 & $; 13 \mathrm{C}$ & 0 & $0 ;(0,3) \mathrm{H}$ & 0 & $5 \mathrm{MR}$ & 0 & $1 \mathrm{MS}$ & 0 \\
\hline CI 14334-1 & 4 & $3+$ & $2+(2+, 4) \mathrm{I}$ & $2++$ & $10 \mathrm{MS}$ & $5 \mathrm{R}$ & $1 \mathrm{R}$ & T MR-MS \\
\hline CI 14334-2 & 4 & 4 & ;2 (;2,4)I & 2 & $\ldots$ & $5 \mathrm{R}$ & $1 \mathrm{R}$ & $\mathrm{T} \mathrm{R}$ \\
\hline CI 14388 & 2 & $; 1++$ LIF & $3(3,3+)$ & $3+$ & $40 \mathrm{MR}$ & $30 \mathrm{MS}-\mathrm{S}$ & $10 \mathrm{M}$ & 0 \\
\hline CI 14396 & $; 1-$ & 3- LIF & $; 1$ & $; 1$ & $20 \mathrm{MR}$ & $10 \mathrm{MS}$ & $10 \mathrm{M}$ & $5 \mathrm{MS}$ \\
\hline CI 15533 & 0 & $; 1+$ LIF & $0 ;(0,0 ;)$ & 0 & $20 \mathrm{M}$ & $5 \mathrm{M}$ & $1 \mathrm{R}$ & T MR \\
\hline CI 15536 & ; & $2++$ & $; 1(0,3) \mathrm{H}$ & 0 & $10 \mathrm{M}$ & $40 \mathrm{~S}$ & $10 \mathrm{MS}$ & T MR \\
\hline CI 15544 & 0 & 3 & $0 ;(0 ;, 4) \mathrm{H}$ & $23-$ & $10 \mathrm{MS}$ & $30 \mathrm{MS}$ & $1 \mathrm{R}$ & $10 \mathrm{MS}-\mathrm{S}$ \\
\hline CI 15555 & $; 11++\mathrm{C}$ & 0 & $; 12-(0 ; 1, ; 13)$ & $2+3$ & $20 \mathrm{MS}$ & $40 \mathrm{~S}$ & $1 \mathrm{MS}$ & T MR \\
\hline CI 15557 & - & - & $; 1(;, ; 1)$ & $; 13$ & $5 \mathrm{MS}$ & $5 \mathrm{MS}$ & $1 \mathrm{R}$ & T MR \\
\hline CI 15564 & $2++$ & $32+$ & $; 1(; 1,3) \mathrm{H}$ & $2+$ & $20 \mathrm{MS}$ & $10 \mathrm{MS}$ & $1 \mathrm{R}$ & $5 \mathrm{MS}$ \\
\hline CI 15612 & ;1- & 0 & $;(0, ; 12-)$ & - & $40 \mathrm{~S} / 10 \mathrm{MR}$ & $5 \mathrm{MS}$ & $1 \mathrm{R}$ & 0 \\
\hline
\end{tabular}

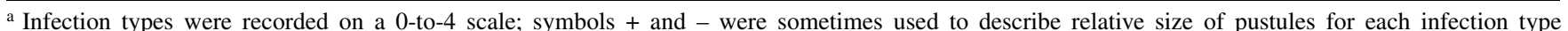
classification. $\mathrm{X}=$ mesothetic reactions, $\mathrm{C}=$ extensive chlorosis associated with infection, $\mathrm{N}=$ extensive necrosis, and LIF $=$ low infection frequency. Infection response categories were resistant (R), moderately resistant (MR), moderately susceptible (MS), and susceptible (S).

b The most frequent infection type observed among four replications is listed followed by the range of infection types observed (separated by commas). If infection types were unique among replicates, then the median infection type was displayed followed by the range. $\mathrm{H}$ designates accessions that were observed to be heterogeneous for resistance and susceptibility within at least one replication, T designates trace severity between zero and five percent infection, and I designates accessions that displayed inconsistent disease reactions among replicates. Data of all replications are available in Supplementary Table 1. 
possible that adult plant resistance independent of Thatcher or $\mathrm{Sr} 2$ exists in this germplasm. Available markers linked to $S r 2$ could be used to screen the germplasm to provide indication of the presence of this gene (9).

The majority of the accessions characterized were resistant at both seedling and adult plant stages to both Kenyan and North American isolates of $P$. graminis f. sp. tritici. Likely, race-specific major genes such as $\mathrm{Sr} 6$ and $\mathrm{Sr} 36$ are contributing to the observed seedling resistance to North American isolates of $P$. graminis $\mathrm{f}$. $\mathrm{sp}$. tritici in this germplasm $(20,21)$. However, few known sources of seedling resistance to race TTKSK (4) and their limited use in cultivars (3) suggest that there could be new sources of seedling resistance to race TTKSK in the germplasm identified. Studies of the genetic control of resistance and of the allelism of this resistance with known race TTKSK resistance sources are needed to characterize the all-stage resistance present in this germplasm. We have initiated the development and characterization of several populations from the 88 accessions to characterize the genetics of resistance in these lines and develop molecular markers linked to resistance genes effective to race TTKSK. The resistant accessions characterized in this study can be incorporated into wheat breeding programs to introgress resistance into adapted cultivars.

\section{Acknowledgments}

Funding for this research was provided by United States Department of Agriculture-Agricultural Research Service, USAID, and Durable Rust Resistance in Wheat. We thank L. Wanschura and Sam Gale for technical assistance.

\section{Literature Cited}

1. Fetch, T., Jr. 2007. Virulence of stem rust race TTKS on Canadian wheat cultivars. Can. J. Plant Pathol. 29:441.

2. Heibert, C. W., Fetch, T. G., Zegeye, T., Thomas, J. B., Somers, D. J., Humphreys, D. G., McCallum, B. D., Cloutier, S., Singh, D., and Knott, D. R 2011. Genetics and mapping of seedling resistance to Ug99 stem rust in Canadian wheat cultivars 'Peace' and 'AC Cadillac'. Theor. Appl. Genet. 122:143-149.

3. Jin., Y., and Singh, R. P. 2006. Resistance in U.S. wheat to recent Eastern African isolates of Puccinia graminis f. sp. tritici with virulence to resistance gene Sr31. Plant Dis. 90:476-480.

4. Jin, Y., Singh, R. P., Ward, R. W., Wanyera, R., Kinyua, M., Njau, P., Fetch, T., Pretorius, Z. A., and Yahyaoui, A. 2007. Characterization of seedling infection types and adult plant infection responses of monogenic $\mathrm{Sr}$ gene lines to race TTKS of Puccinia graminis f. sp. tritici. Plant Dis. 91:1096-1099.

5. Jin, Y., Szabo, L. J., Pretorius, Z. A., Singh, R. P., Ward, R., and Fetch, T., Jr. 2008. Detection of virulence to resistance gene $S r 24$ within race TTKS of Puccinia graminis f. sp. tritici. Plant Dis. 92:923-926.

6. Jin, Y., Szabo, L. J., Rouse, M. N., Fetch, T., Jr., Pretorus, Z. A., Wanyera, R., and Njau, P. 2009. Detection of virulence to resistance gene $\operatorname{Sr} 36$ within

Table 2. (continued from preceding page)

\begin{tabular}{|c|c|c|c|c|c|c|c|c|}
\hline Accession & TPMKC & TTTTF & TTKSK $^{b}$ & TTKST & 2005 Njoro & 2006 Njoro & 2007 Njoro & 2006 St. Paul \\
\hline CI 15623 & 0 & 0 & $0 ;(0, ; 1)$ & ;2 & $20 \mathrm{MS}$ & $5 \mathrm{MS}$ & $1 \mathrm{R}$ & 0 \\
\hline CI 15624 & 0 & 0 & $0 ;(0 ;, ; 1)$ & $; 1$ & $10 \mathrm{MR}$ & $5 \mathrm{MS}$ & $1 \mathrm{R}$ & 0 \\
\hline CI 15658 & 0 & $2++$ & $;(;, ; 12)$ & ;13 & $10 \mathrm{R}$ & $1 \mathrm{MS}$ & 0 & 0 \\
\hline CI 15679 & ;12- & $3+$ & $3(2+, 3) \mathrm{I}$ & $3-$ & $20 \mathrm{MR}$ & $10 \mathrm{MS}$ & $1 \mathrm{R}$ & 0 \\
\hline CI 15680 & 2 & 0 & $3(2++, 3) \mathrm{I}$ & 3 & $20 \mathrm{MR}$ & $5 \mathrm{R}-\mathrm{MR} / 10 \mathrm{MS}$ & $1 \mathrm{R}$ & 0 \\
\hline CI 15681 & 2 & $; 1$ & $3(2+, 4) \mathrm{I}$ & 3 & $10 \mathrm{MR}$ & 5 R-MR & $1 \mathrm{MS}$ & T MR \\
\hline CI 15682 & 2 & 0 & $4(2,4) \mathrm{I}$ & - & $20 \mathrm{MS}$ & $5 \mathrm{R}-\mathrm{MR} / 5 \mathrm{~S}$ & 0 & 0 \\
\hline CI 15685 & 3 & $1++$ & $0 ;(0 ;, 4) \mathrm{H}$ & $0 ; 1-$ & $5 \mathrm{R}$ & 0 & 0 & 0 \\
\hline CI 15686 & 2 & $3+$ & $3+(;, 4) \mathrm{I}$ & 4 & $10 \mathrm{R}$ & $10 \mathrm{MS}-\mathrm{S}$ & 0 & $\mathrm{~T} \mathrm{MR}$ \\
\hline CI 15711 & 0 & - & $0 ; 1(0 ;, 3) \mathrm{H}$ & $; 1-$ & $20 \mathrm{MR}$ & $10 \mathrm{MS}$ & 0 & 5 R-MR \\
\hline CI 15716 & $; 13 \mathrm{C}$ & $3+$ & $0 ;(0 ;, ;)$ & - & $10 \mathrm{MR}$ & $30 \mathrm{R} / 10 \mathrm{MS}$ & $1 \mathrm{MR}$ & $5 \mathrm{MR}$ \\
\hline CI 15853 & - & - & $3(2,3) \mathrm{I}$ & $3-$ & $5 \mathrm{MR}$ & $\ldots$ & $5 \mathrm{R}$ & $\ldots$ \\
\hline PI 185876 & 3 & $3+$ & $23-\mathrm{C}(23-\mathrm{C}, 4) \mathrm{I}$ & 4 & $30 \mathrm{MR}$ & $20 \mathrm{MR} / 40 \mathrm{MS}$ & $5 \mathrm{R}$ & 10 MR-MS \\
\hline PI 199813 & - & - & $4(23,4) \mathrm{I}$ & 3 & $20 \mathrm{MR}$ & $10 \mathrm{MS}$ & $1 \mathrm{MS}$ & $\ldots$ \\
\hline PI 234234 & - & - & 4 & 4 & $5 \mathrm{MR}$ & $\ldots$ & $70 \mathrm{~S}$ & $\ldots$ \\
\hline PI 234235 & 3 & 4 & $0 ;(0,0 ;)$ & 0 & $5 \mathrm{R}$ & 0 & 30 MSS & $5 \mathrm{MR}, \mathrm{T} \mathrm{S}$ \\
\hline PI 234236 & 4 & 4 & $0(0,3) \mathrm{H}$ & 0 & $5 \mathrm{R}$ & 0 & $40 \mathrm{MSS}$ & $5 \mathrm{MS}-\mathrm{S}$ \\
\hline PI 234237 & $3 \mathrm{LIF}$ & 4 & $0(0,4) \mathrm{H}$ & 0 & $5 \mathrm{R}$ & 0 & $1 \mathrm{MS}$ & $5 \mathrm{MR}-\mathrm{MS}$ \\
\hline PI 234238 & - & $2++$ & $0 ;(0,0 ;)$ & 0 & $5 \mathrm{R}$ & 0 & $1 \mathrm{MS}$ & $5 \mathrm{MS}$ \\
\hline PI 234239 & 32 & $2++$ & $0 ;(0, ;)$ & 0 & $5 \mathrm{R}$ & 0 & $1 \mathrm{MS}$ & $5 \mathrm{MR}-\mathrm{MS}$ \\
\hline PI 238391 & 32 & $2++$ & $0 ;(0 ;, ; 1)$ & ;13 & $30 \mathrm{MR}$ & $5 \mathrm{M}$ & $1 \mathrm{MS}$ & $5 \mathrm{MR}$ \\
\hline PI 254119 & $3+2$ & $32+$ & $\mathrm{X}(0,3) \mathrm{H}$ & 3 & $20 \mathrm{MS}$ & $5 \mathrm{MR}$ & $1 \mathrm{MR}$ & $10 \mathrm{MS}$ \\
\hline PI 254121 & $; 3 \mathrm{~N}$ & $3+$ & $0(0,0 ;)$ & ; & $10 \mathrm{MS}$ & $1 \mathrm{MR}$ & $1 \mathrm{R}$ & $5 \mathrm{MS}$ \\
\hline PI 254124 & 4 & $3+$ & $0(0, ; 1)$ & 4 & $10 \mathrm{MR}$ & $1 \mathrm{R}$ & $5 \mathrm{MS}$ & $10 \mathrm{MR}-\mathrm{MS}$ \\
\hline PI 254126-2 & - & - & $0(0, ;)$ & $; 1$ & $10 \mathrm{MR}$ & $1 \mathrm{R}$ & $1 \mathrm{MR}$ & $5 \mathrm{MS}$ \\
\hline PI 254137 & $2+\mathrm{N}$ & $22+$ & ;2C $(0,3) \mathrm{I}$ & 3 & $20 \mathrm{MR}$ & $1 \mathrm{MR}$ & 0 & T MS \\
\hline PI 254138 & 3 & $2+$ & ;3- $(0,4) \mathrm{H}$ & - & $60 \mathrm{~S} / 20 \mathrm{MR}$ & $5 \mathrm{MS}-\mathrm{S}$ & $5 \mathrm{MR}$ & $60 \mathrm{~S}$ \\
\hline PI 286545 & $3+$ & 3 & $4(0 ; 2+, 4) \mathrm{I}$ & 4 & $20 \mathrm{MS}$ & $5 \mathrm{MR}$ & $1 \mathrm{MR}$ & $5 \mathrm{MR}$ \\
\hline PI 286546 & 2 & 2 & $3+(3+, 4)$ & 4 & $20 \mathrm{MS}$ & $1 \mathrm{M}$ & $1 \mathrm{MR}$ & 0 \\
\hline PI 297024 & $2++$ & 4 & $; 1-(0 ;, 2 \mathrm{C})$ & ; & $10 \mathrm{MR}$ & 0 & 0 & 0 \\
\hline PI 299414 & $; 1 \mathrm{C}$ & ; & $3-(2,3-) \mathrm{I}$ & $2++$ & $10 \mathrm{MR}$ & $5 \mathrm{MS}$ & $5 \mathrm{MS}$ & 0 \\
\hline PI 323400 & ;23 & $3-2$ & $0(0,0 ;)$ & 0 & $5 \mathrm{MR}$ & 0 & $1 \mathrm{MR}$ & 0 \\
\hline PI 410954 & 2 & 2 & $2-(0 ;, 2)$ & $2++$ & $20 \mathrm{MS}$ & 0 & $5 \mathrm{R}$ & T MR \\
\hline PI 480270 & ;2 & $3+$ & $; 1-(0, ; 1-)$ & 0 & $10 \mathrm{M}$ & 0 & $5 \mathrm{MS}$ & 0 \\
\hline PI 518648 & 2 & 0 & $3(3,4)$ & 3 & $40 \mathrm{MR}$ & $30 \mathrm{~S}$ & $5 \mathrm{M}$ & 0 \\
\hline PI 519501 & $; 1$ & 2- LIF & $0(0,0 ;)$ & 0 & $10 \mathrm{MR}$ & $5 \mathrm{M}$ & $1 \mathrm{R}$ & 0 \\
\hline PI 519503 & $3-\mathrm{C}$ & $0 ; 1$ & $0(0,4) \mathrm{H}$ & 0 & $10 \mathrm{MS}$ & $5 \mathrm{MS}$ & 0 & 0 \\
\hline PI 519553 & 0 & - & $0(0,0 ;)$ & 0 & $10 \mathrm{R}$ & 0 & $1 \mathrm{MS}$ & 0 \\
\hline PI 519623 & $2 \mathrm{~N}$ & 4 & $3(0,3) \mathrm{I}$ & 31 & $20 \mathrm{R}$ & $20 \mathrm{MS}-\mathrm{S}$ & $5 \mathrm{M}$ & 0 \\
\hline PI 519681 & 0 & 0 & $3-(3-, 4)$ & 3 & $10 \mathrm{R}$ & $30 \mathrm{MS}-\mathrm{S}$ & $5 \mathrm{M}$ & $\mathrm{T} \mathrm{MR} / 20 \mathrm{MS}$ \\
\hline PI 519711 & 0 & $0 ; / ; 2$ & $0(0,4) \mathrm{H}$ & 0 & $10 \mathrm{R}$ & 0 & 0 & 0 \\
\hline PI 519720 & ;3- & $3-1$ & $0 ;(0, ; 1-)$ & 0 & $10 \mathrm{R}$ & 0 & 0 & 0 \\
\hline PI 519805 & 2 & $2-$ & $1(1,2+)$ & 2 & $10 \mathrm{R}$ & $1 \mathrm{MR}$ & $5 \mathrm{M}$ & 0 \\
\hline PI 519943 & 0 & $3+$ & $0(0,0 ;)$ & 0 & $10 \mathrm{MR}$ & 0 & 0 & 0 \\
\hline PI 520033 & $1+$ & ; & $0 ;(0 ;, 0 ; 1)$ & 0 & $10 \mathrm{R}$ & 0 & $1 \mathrm{R}$ & 0 \\
\hline PI 520093 & 0 & 0 & $0(0,0 ;)$ & 0 & $5 \mathrm{R}$ & 0 & $1 \mathrm{R} / 5 \mathrm{~S}$ & 0 \\
\hline PI 520265 & 2 & 0 & $0(0,3) \mathrm{H}$ & $2+$ & $10 \mathrm{MR} / 50 \mathrm{~S}$ & 0 & $5 \mathrm{MS}$ & 0 \\
\hline PI 520373 & 2 & $3-$ & $0(0,3-) \mathrm{I}$ & $3-$ & $5 \mathrm{MS}$ & $10 \mathrm{MS}-\mathrm{S}$ & $1 \mathrm{M}$ & 0 \\
\hline LMPG-6 & 4 & $2+$ & $3(3,4)$ & 4 & $60 \mathrm{MS}-\mathrm{S}$ & $60 \mathrm{~S}$ & $70 \mathrm{~S}$ & $60 \mathrm{~S}$ \\
\hline
\end{tabular}


the TTKS race lineage of Puccinia graminis f. sp. tritici. Plant Dis. 93:367370 .

7. Knott, D. R. 1990. Near-isogenic lines of wheat carrying genes for stem rust resistance. Crop Sci. 30:901-905.

8. Leonard, K. J. 2001. Stem rust-future enemy? Pages 119-146 in: Stem Rust of Wheat: From Ancient Enemy to Modern Foe. P. D. Peterson ed. American Phytopathological Society, St. Paul, MN.

9. Mago, R., Brown-Geudira, G., Dreisigacker, S., Breen, J., Jin, Y., Singh, R., Appels, R., Lagudah, E. S., Ellis, J., and Spielmeyer, W. 2011. An accurate DNA marker assay for stem rust resistance gene $S r 2$ in wheat. Theor. Appl. Genet. 122:735-744.

10. Nazari, K., Mafi, M., Yahyaoui, A., Singh, R. P., and Park, R. F. 2009. Detection of wheat stem rust (Puccinia graminis f. sp. tritici) race TTKSK (Ug99) in Iran. Plant Dis. 93:317.

11. Njau, P. N., Jin, Y., Huerta-Espino, J., Keller, B., and Singh, R. P. 2010. Identification and evaluation of sources of resistance to stem rust race Ug99 in wheat. Plant Dis. 94:413-419.

12. Peterson, R. F., Campbell, A. B., and Hannah, A. E. 1948. A diagrammatic scale for estimating rust intensity of leaves and stem of cereals. Can. J. Res. Sect. C 26:496-500.

13. Pretorius, Z. A., Bender, C. M., Visser, B., and Terefe, T. 2010. First report of a Puccinia graminis f. sp. tritici race virulent to the $S r 24$ and $S r 31$ wheat stem rust resistance genes in South Africa. Plant Dis. 94:784.

14. Pretorius, Z. A., Singh, R. P., Wagoire, W. W., and Payne, T. S. 2000. Detec- tion of virulence to wheat stem rust resistance gene Sr31 in Puccinia graminis f. sp. tritici in Uganda. Plant Dis. 84:203.

15. Roelfs, A. P. 1978. Estimated losses caused by rust in small grain cereals in the United States: 1918-76. U. S. Dep. Agric. Agric. Res. Serv. Misc. Publ. 1363.

16. Roelfs, A. P., Singh, R. P., and Saari, E. E. 1992. Rust Diseases of Wheat: Concepts and Methods of Disease Management. CIMMYT, Mexico, D.F.

17. Rowell, J. B. 1984. Controlled infection by Puccinia graminis f. sp. tritici under artificial conditions. Pages 292-332 in: The Cereal Rusts, Vol. 1. Origins, Specificity, Structure, and Physiology. W. R. Bushnell and A. P. Roelfs, eds. Academic Press, Orlando, FL.

18. Singh, R. P., Hodson, D. P., Huerta-Espino, J., Jin, Y., Njau, P., Wanyera, R., Herrera-Foessel, S. A., and Ward, R. 2008. Will stem rust destroy the world's wheat crop? Adv. Agron. 98:271-309.

19. Stakman, E. C., Steward, D. M., and Loegering, W. Q. 1962. Identification of physiologic races of Puccinia graminis var. tritici. U. S. Dep. Agric. Agric. Res. Serv. E-617.

20. Tsilo, T. J., Chao, S., Jin, Y., and Anderson, J. A. 2009. Identification and validation of SSR markers linked to the stem rust resistance gene Sr6 on the short arm of chromosome 2D in wheat. Theor. Appl. Genet. 118:515524.

21. Tsilo, T. J., Jin, Y., and Anderson, J. A. 2008. Diagnostic microsatellite markers for the detection of stem rust resistance gene Sr36 in diverse genetic backgrounds of wheat. Crop Sci. 48:253-261. 